\title{
HUBUNGAN ANTARA ASUPAN KALSIUM DAN ASUPAN ZAT BESI DENGAN KEJADIAN DISMENORE PADA SISWI DI SMK BATIK 2 SURAKARTA
}

\author{
Kartika Rohmah Hidayati ${ }^{1}$, Elida Soviana ${ }^{2}$, Nur Lathifah Mardiyati ${ }^{3}$ \\ ${ }^{1}$ Alumni Program Studi DIII Gizi FIK UMS. Jl. A. Yani Tromol Pos I Pabelan \\ Surakarta. Email: ${ }^{1}$ kartikarh08@ gmail.com \\ ${ }^{2,3}$ Program Studi Ilmu Gizi FIK UMS. Jl. A. Yani Tromol Pos I Pabelan Surakarta. \\ Email: 2elida.soviana@ums.ac.id ${ }^{3}$ nlm233@ums.ac.id
}

\begin{abstract}
ABSTRAK
Dismenore merupakan nyeri di bawah perut yang terjadi menjelang atau selama menstruasi. Di Indonesia diperkirakan 55\% wanita usia subur mengalami dismenore. Terdapat beberapa faktor yang dapat memengaruhi dismenore, salah satunya yaitu asupan zat gizi. Beberapa asupan zat gizi yang berhubungan dengan dismenore yaitu kalsium dan zat besi. Penelitian ini bertujuan untuk mengetahui hubungan antara asupan kalsium dan zat besi dengan kejadian dismenore pada siswi di SMK Batik 2 Surakarta. Jenis penelitian bersifat observasional dengan pendekatan cross-sectional. Pengumpulan data asupan kalsium dan zat besi menggunakan form food frequency semi kuantitatif, data kejadian dismenore menggunakan Universal Pain Assessment Tool. Jumlah responden sebanyak 67 yang diambil menggunakan teknik simple random sampling. Uji hubungan menggunakan uji Rank Spearman. Hasil penelitian menunjukkan sebagian besar responden memiliki asupan kalsium (83.6\%) dan asupan zat besi (71.6\%) kategori kurang, sedangkan sebagian besar kejadian dismenore yang dialami termasuk dalam kategori nyeri sedang 1 (22.4\%). Penelitian tersebut juga menunjukkan adanya hubungan antara asupan kalsium dengan kejadian dismenore dengan $p$-value 0.000 dan nilai $\mathrm{r}=-0.415$. Terdapat pula hubungan antara asupan zat besi dengan kejadian dismenore dengan $\mathrm{p}$-value 0.000 dan nilai $\mathrm{r}=-0.586$. Terdapat hubungan antara asupan kalsium dan asupan zat besi dengan kejadian dismenore pada siswi di SMK Batik 2 Surakarta. Semakin tinggi asupan kalsium dan zat besi, maka semakin rendah kejadian dismenore yang dirasakan.
\end{abstract}

Kata Kunci : asupan kalsium, asupan zat besi, dismenore

ABSTRACT

Dismenore is a stiffness in the lower abdomen that occurs before or during menstruation.In Indonesia,approximately $55 \%$ of child bearing women experienced dismenore. There are some factors that affect dismenore, one of them is nutrient intake. Some nutrient intake associated with dismenore are calcium and iron. The purposes of this research were to know the correlation between calcium and iron 
intakes and dismenore pain among female students at Vocational High School of Batik 2 Surakarta. This research was an observational study using cross-sectional design. Calcium and iron intakes data were collected using semi-quantitative food frequency questionnaire, data about dismenore pain were obtained through Universal Pain Assessment Tool. There were 67 respondents participated and taken using simple random sampling method. The correlation test used Rank Spearman test. The resultshowed that most participants had low calcium (83.6\%) and iron intakes (71.6\%). While most of dismenorepain were classified as moderate pain 1 (22.4\%).The research also showed a correlation between calcium and dismenore pain, with a p-value of 0.000 andr value $=-0.415$. Also there was a correlation between iron intake and dismenore incidence with $\mathrm{p}$-value 0.000 and $r$ value $=-0.586$. There were correlation between calcium and iron intake anddismenore among female students atVocational High School of Batik 2 Surakarta. The higher calcium and iron intakes, less painful dismenore felt.

Keywords : calcium intake, iron intake, dismenore

\section{PENDAHULUAN}

Dismenore merupakan nyeri di bagian bawah perut yang terjadi pada waktu menjelang atau selama menstruasi. Gejala dismenore dapat disertai dengan rasa mual, muntah, diare dan kram. Di Indonesia angka kejadian diperkirakan $55 \%$ perempuan produktif yang mengalami dismenore. Prevalensi dismenore berkisar 45-95\% di kalangan wanita usia produktif (Proverawati dan Misaroh, 2009).

Faktor penyebab dismenore antara lain: kejiwaan, individual, sumbatan di saluran leher rahim, organ reproduksi wanita, endokrin, dan alergi (Yahya, 2011). Asupan nutrisi juga memiliki pengaruh terhadap kejadian dismenore. Zat gizi yang berpengaruh antara lain adalah kalsium dan zat besi. Kalsium memiliki peranan sebagai zat yang diperlukan untuk kontraksi otot. Kalsium berperan dalam interaksi protein di dalam otot, yaitu aktin dan miosin pada saat otot berkontraksi. Kekurangan kalsium menyebabkan otot tidak dapat mengendur setelah kontraksi, sehingga dapat mengakibatkan otot menjadi kram (Yuliarti, 2009).

Berdasarkan penelitian yang dilakukan oleh Sinaga (2012), menyatakan bahwa ada hubungan antara konsumsi kalsium dengan dismenore. Penelitian yang dilakukan pada remaja putri vegan di Vihara Maitreya Medan menunjukkan $77,5 \%$ memiliki asupan kalsium yang rendah.

Zat besi memiliki peranan dalam pembentukan hemoglobin. Kekurangan asupan zat besi menyebabkan terganggunya pembentukan hemoglobin, sehingga jumlah hemoglobin dalam sel darah merah akan berkurang. Kondisi hemoglobin yang rendah pada sel darah merah, menyebabkan tubuh kekurangan oksigen dan menyebabkan anemia. Menurut Sylvia dan Lorrainne (2006), anemia merupakan salah satu faktor konstitusi penyebab kurangnya daya tahan tubuh terhadap rasa nyeri saat menstruasi. Anemia tidak hanya menjadi salah satu penyebab terjadinya dismenore, namun juga dapat memperparah dismenore. 
Berdasarkan penelitian yang dilakukan Sophia dkk (2013), menyatakan bahwa pada siswi SMK Negeri 10 Medan menunjukkan $88 \%$ dari 171 siswi memiliki status gizi kurang (underweight) dengan anemia. Perempuan dengan anemia memiliki resiko 1,2 kali lebih besar mengalami dismenore. Dismenore yang dialami dapat diakibatkan oleh anemia defisiensi zat besi, dimana zat besi memiliki peranan untuk kekebalan tubuh terhadap rasa nyeri.

Berdasarkan studi pendahuluan yang dilakukan pada tanggal 10 sampai 14 November 2014 , didapatkan siswi kelas XI di SMK Batik 2 Surakarta sebanyak 163 orang. Dari jumlah tersebut, $21.5 \%$ mengalami nyeri ringan, $35.6 \%$ mengalami nyeri sedang $1, \quad 17.2 \%$ mengalami nyeri sedang 2, $11.6 \%$ mengalami nyeri berat, $5.5 \%$ mengalami nyeri tak tertahankan dan $8.6 \%$ tidak mengalami nyeri dismenore pada saat atau menjelang menstruasi.

Berdasarkan latar belakang diatas, maka peneliti akan meneliti tentang "hubungan antara asupan kalsium dan asupan zat besi dengan kejadian dismenore pada siswi di SMK Batik 2 Surakarta".

\section{METODE PENELITIAN}

Jenis penelitian ini adalah observational dengan pendekatan crosssectional. Responden dalam penelitian ini yaitu 67 siswi SMK Batik 2 Surakarta. Responden diambil dengan teknik simpel random sampling.

Pengumpulan data asupan kalsium dan zat besi menggunakan form food frequency semi kuantitatif. Data ini kemudian diolah menggunakan program Nutrisurvey. Total asupan kalsium dan zat besi dibandingkan dengan Angka Kecukupan Gizi (2013) kemudian dikali 100\%. Tingkat asupan kalsium dan zat besi dikatakan kurang jika prosentasenya $<80 \%$ AKG, dikatakan baik jika prosentasenya $80-100 \% \quad \mathrm{AKG}$, dan dikatakan lebih jika prosentasenya $>100 \%$ (Supariasa, 2002).

Data kejadian dismenore diperoleh dengan cara wawancara menggunakan kuesioner Universal Pain Assessment Tool. Data kejadian dismenore dikategorikan menjadi tidak nyeri, nyeri ringan, nyeri sedang 1 , nyeri sedang 2 , nyeri berat, dan nyeri tak tertahankan.

Analisis data menggunakan program SPSS for Windows versi 17.0. Data hubungan asupan kalsium dan asupan zat besi dengan kejadian dismenore dianalisis menggunakan uji statistik Rank Spearman. Signifikansi nilai $p$ adalah jika nilai $p<0.05$ maka $\mathrm{H} 0$ ditolak, berarti ada hubungan antara asupan kalsium dan asupan zat besi dengan kejadian dismenore pada siswi di SMK Batik 2 Surakarta dan jika nilai $p>0.05$ maka $\mathrm{H} 0$ diterima, berarti tidak ada hubungan antara asupan kalsium dan asupan zat besi dengan kejadian dismenore pada siswi di SMK Batik 2 Surakarta.

\section{HASIL DAN PEMBAHASAN}

\section{Distribusi Responden berdasarkan Asupan Kalsium}

Distribusi responden berdasarkan asupan kalsium dapat dilihat pada Tabel 1.

Tabel 1. Distribusi Responden berdasarkan Asupan Kalsium

\begin{tabular}{ccc}
\hline Asupan & Jumlah & Prosentase (\%) \\
Kalsium & & \\
\hline Kurang & 56 & 83.6 \\
Normal & 11 & 16.4 \\
Lebih & 0 & 0 \\
Total & 67 & 100 \\
\hline
\end{tabular}

(Sumber: Data Primer, 2015)

Berdasarkan data Tabel 1, mayoritas asupan kalsium responden termasuk dalam kategori kurang yaitu $83.6 \%$. Asupan kalsium terendah yaitu $138 \mathrm{mg}$ 
dan asupan kalsium tertinggi yaitu 1036.8 mg. Rata-rata asupan kalsium responden $437.7 \mathrm{mg} / \mathrm{hari}$. Angka tersebut masih jauh dari kebutuhan kalsium remaja putri dengan rentang usia 16 sampai 18 tahun yaitu $1200 \mathrm{mg} /$ hari (AKG, 2013). Kurangnya asupan kalsium berdasarkan kebutuhan dapat dipengaruhi oleh rendahnya makanan sumber kalsium yang dikonsumsi. Hal ini dapat dilihat dari hasil food frequency yang menunjukkan responden jarang mengkonsumsi makanan sumber kalsium. Berdasarkan hasil food frequency, sumber kalsium yang paling banyak dikonsumsi oleh responden yaitu daging ayam, telur ayam, tempe dan tahu. Menurut Puspasari (2004), asupan kalsium juga dapat dipengaruhi oleh tingkat pengetahuan seseorang.

\section{Distribusi Responden berdasarkan Asupan Zat Besi}

Distribusi responden berdasarkan asupan zat besi dapat dilihat pada Tabel 2 .

Tabel 2. Distribusi Responden berdasarkan Asupan Zat Besi

\begin{tabular}{ccc}
\hline Asupan Zat Besi & Jumlah & Prosentase (\%) \\
\hline Kurang & 46 & 71.6 \\
Normal & 19 & 28.4 \\
Lebih & 0 & 0 \\
Total & 67 & 100 \\
\hline
\end{tabular}

(Sumber: Data Primer, 2015)

Berdasarkan Tabel 2, sebagian besar responden memiliki asupan zat besi yang kurang yaitu $71.6 \%$. Asupan zat besi terendah yaitu $2.2 \mathrm{mg} / \mathrm{hari}$ dan asupan tertinggi yaitu $15.4 \mathrm{mg} / \mathrm{hari}$. Rata-rata asupan zat besi responden yaitu 7.6 $\mathrm{mg} /$ hari. Jumlah tersebut masih jauh dari kebutuhan zat besi bagi remaja putri dengan rentang usia 16 sampai 18 tahun yaitu $15 \mathrm{mg} /$ hari (AKG, 2013). Asupan zat besi yang kurang dari kebutuhan dapat disebabkan karena rendahnya frekuensi konsumsi makanan sumber zat besi. Berdasarkan hasil food frequency, sumber zat besi yang paling banyak dikonsumsi oleh responden yaitu daging ayam, hati ayam, telur ayam, tempe kedelai dan tahu. Rendahnya asupan zat besi dapat disebabkan karena tingkat sosial ekonomi. Tingkat sosial ekonomi dapat mempengaruhi daya beli terhadap aneka ragam pangan. Rendahnya tingkat sosial ekonomi menyebabkan seseorang tidak mampu membeli dan memilih pangan yang bermutu gizi baik serta beragam (Dieny, 2014).

\section{Distribusi Responden berdasarkan Kejadian Dismenore}

Distribusi responden berdasarkan kejadian dismenore dapat dilihat pada Tabel 3.

Tabel 3. Distribusi Responden Berdasarkan Kejadian Dismenore

\begin{tabular}{ccc}
\hline $\begin{array}{c}\text { Kejadian } \\
\text { Dismenore }\end{array}$ & Jumlah & $\begin{array}{c}\text { Prosentase } \\
(\%)\end{array}$ \\
\hline Tidak nyeri & 12 & 17.9 \\
Nyeri ringan & 14 & 20.9 \\
Nyeri sedang 1 & 15 & 22.4 \\
Nyeri sedang 2 & 12 & 17.9 \\
Nyeri berat & 11 & 16.4 \\
Nyeri tak & 3 & 4.5 \\
tertahankan & & \\
Total & 67 & 100 \\
\hline
\end{tabular}

(Sumber: Data Primer, 2015)

Kejadian dismenore dalam penelitian ini diukur menggunakan Universal Pain Assessment Tool. Berdasarkan Tabel 3, sebagian besar responden mengalami dismenore dengan tingkat nyeri sedang 1 yaitu $22.4 \%$ dan kejadian dismenore terendah terjadi pada kategori nyeri tak tertahankan sebesar $4.5 \%$.

Dismenore dapat terjadi karena beberapa faktor, salah satunya yaitu asupan zat gizi. Seorang wanita yang 
memiliki asupan zat gizi rendah, beresiko lebih tinggi untuk mengalami dismenore (Sophia dkk, 2013). Tingginya angka kejadian dismenore dapat menjadi salah satu gambaran dari permasalahan gizi pada remaja.

Menurut (Yahya, 2011) terdapat faktor-faktor lain yang menyebabkan terjadinya dismenore, antara lain faktor endokrin, faktor kejiwaan atau stres dan faktor organ reproduksi wanita.

\section{Hubungan Antara Asupan Kalsium dengan Kejadian Dismenore}

Hasil uji hubungan antara asupan kalsium dengan kejadian dismenore pada siswi di SMK Batik 2 Surakarta dapat dilihat dalam Tabel 4.

Tabel 4. Hubungan Asupan Kalsium dengan Kejadian Dismenore

\begin{tabular}{|c|c|c|c|c|c|c|c|c|c|c|c|c|c|c|c|c|}
\hline \multirow{3}{*}{ No } & \multirow{3}{*}{$\begin{array}{l}\text { Asupan } \\
\text { Kalsium }\end{array}$} & \multicolumn{12}{|c|}{ Kejadian Dismenore } & & & \multirow{3}{*}{$p$} \\
\hline & & \multicolumn{2}{|c|}{$\begin{array}{l}\text { Tidak } \\
\text { Nyeri }\end{array}$} & \multicolumn{2}{|c|}{$\begin{array}{l}\text { Nyeri } \\
\text { Ringan }\end{array}$} & \multicolumn{2}{|c|}{$\begin{array}{c}\text { Nyeri } \\
\text { Sedang } 1\end{array}$} & \multicolumn{2}{|c|}{$\begin{array}{c}\text { Nyeri } \\
\text { Sedang } 2\end{array}$} & \multicolumn{2}{|c|}{ Nyeri Berat } & \multicolumn{2}{|c|}{$\begin{array}{c}\text { Nyeri } \\
\text { Tak } \\
\text { Tertahan } \\
\text { kan }\end{array}$} & \multicolumn{2}{|c|}{ Total } & \\
\hline & & $\mathrm{n}$ & $\%$ & $\mathrm{n}$ & $\%$ & $\mathrm{n}$ & $\%$ & $\mathrm{n}$ & $\%$ & $\mathrm{n}$ & $\%$ & $\mathrm{n}$ & $\%$ & $\mathrm{~N}$ & $\%$ & \\
\hline 1 & Kurang & 7 & 12.5 & 10 & 17.9 & 13 & 23.2 & 12 & 21.4 & 11 & 19.6 & 3 & 5.4 & 56 & 100 & 0 \\
\hline 2 & Normal & 5 & 45.5 & 4 & 36.4 & 2 & 18.1 & 0 & 0 & 0 & 0 & 0 & 0 & 11 & 100 & .000 \\
\hline
\end{tabular}

(Sumber: Data Primer, 2015)

Berdasarkan Tabel 4, sebagian besar responden berkategori asupan kalsium kurang $(23.2 \%)$ merasakan nyeri sedang 1. Responden yang memiliki asupan kalsium normal menunjukkan lebih sedikit yang mengalami nyeri dibandingkan dengan responden dengan asupan kalsium rendah. Hasil uji statistik menggunakan uji Rank Spearman diperoleh nilai $\mathrm{r}=$ 0.415 dan $p$-value sebesar $0.000(p<0.05)$ yang berarti ada hubungan signifikan antara asupan kalsium dengan kejadian dismenore pada siswi di SMK Batik 2 Surakarta. Nilai $\mathrm{r}-0.415$ menunjukkan adanya hubungan yang sedang antara kedua variabel (Sugiyono, 2002). Nilai $r$ yang negatif menunjukkan bahwa semakin tinggi asupan kalsium maka rasa nyeri semakin berkurang.

Hasil penelitian ini sejalan dengan penelitian yang dilakukan oleh Oktabriawatie dkk (2009) pada remaja putri di SMA N 6 Tangerang. Hasil penelitian menunjukkan bahwa ada hubungan yang signifikan antara konsumsi kalsium dengan keluhan menstruasi pada remaja putri. Penelitian sejenis juga dilakukan oleh Jacobs (2000) yang memberikan suplemen kalsium karbonat $1200 \mathrm{mg} /$ hari selama 3 siklus menstruasi pada 472 wanita. Hasil penelitian tersebut menunjukkan bahwa kalsium terbukti $48 \%$ dapat menurunkan atau mengurangi rasa sakit menjelang menstruasi. Penelitian pada remaja wanita di SMA 8 Denpasar juga menunjukkan adanya hubungan antara tingkat konsumsi kalsium dengan kejadian dismenore. Hal ini dikarenakan pada penelitian tersebut, 95\% remaja wanita yang tingkat asupan kalsiumnya rendah mengalami dismenore.

Kalsium merupakan salah satu mineral yang sangat dibutuhkan oleh remaja. Kalsium tidak hanya dibutuhkan untuk pertumbuhan tulang, bagi remaja putri kalsium juga diperlukan untuk mengurangi atau bahkan menghindarkan rasa nyeri menjelang atau saat menstruasi atau yang yang biasa disebut dengan dismenore. Asupan kalsium berpengaruh pada permeabilitas membran syaraf. 
Rendahnya asupan kalsium menyebabkan otot tidak dapat mengendur sehingga otot menjadi kram (FKM UI, 2013). Seorang remaja wanita juga perlu mengurangi makanan berlemak tinggi yang dapat menyebabkan terjadinya nyeri menjelang atau selama menstruasi (Widjanarko, 2006).

\section{Hubungan Antara Asupan Zat Besi dengan Kejadian Dismenore}

Hasil uji hubungan antara asupan zat besi dengan kejadian dismenore pada siswi di SMK Batik 2 Surakarta dapat dilihat dalam Tabel 5.

Tabel 5. Hubungan Antara Asupan Zat Besi dengan Kejadian Dismenore

\begin{tabular}{|c|c|c|c|c|c|c|c|c|c|c|c|c|c|c|c|c|}
\hline \multirow{3}{*}{ No } & \multirow{3}{*}{$\begin{array}{c}\text { Asupan } \\
\text { Zat } \\
\text { Besi }\end{array}$} & \multicolumn{12}{|c|}{ Kejadian Dismenore } & \multirow{2}{*}{\multicolumn{2}{|c|}{ Total }} & \multirow{3}{*}{$p$} \\
\hline & & \multicolumn{2}{|c|}{$\begin{array}{l}\text { Tidak } \\
\text { Nyeri }\end{array}$} & \multicolumn{2}{|c|}{$\begin{array}{c}\text { Nyeri } \\
\text { Ringan }\end{array}$} & \multicolumn{2}{|c|}{$\begin{array}{c}\text { Nyeri } \\
\text { Sedang } \\
1\end{array}$} & \multicolumn{2}{|c|}{$\begin{array}{c}\text { Nyeri } \\
\text { Sedang } \\
2\end{array}$} & \multicolumn{2}{|c|}{$\begin{array}{l}\text { Nyeri } \\
\text { Berat }\end{array}$} & \multicolumn{2}{|c|}{$\begin{array}{c}\text { Nyeri Tak } \\
\text { Tertahan } \\
\text { kan }\end{array}$} & & & \\
\hline & & $\mathrm{n}$ & $\%$ & $\mathrm{n}$ & $\%$ & $\mathrm{n}$ & $\%$ & $\mathrm{n}$ & $\%$ & $\mathrm{n}$ & $\%$ & $\mathrm{n}$ & $\%$ & $\mathrm{~N}$ & $\%$ & \\
\hline 1 & Kurang & 4 & 8.3 & 6 & 12.5 & 12 & 25 & 12 & 25 & 11 & 23 & 3 & 6.2 & 48 & 100 & 0.000 \\
\hline 2 & Normal & 8 & 42 & 8 & 42 & 3 & 16 & 0 & 0 & 0 & 0 & 0 & 0 & 19 & 100 & \\
\hline
\end{tabular}

(Sumber: Data Primer, 2015)

Berdasarkan Tabel 5, sebagian besar responden memiliki asupan zat besi kurang serta merasakan nyeri sedang 1 dan nyeri sedang $2(25 \%)$. Responden yang memiliki asupan zat besi pada kategori kurang, lebih besar mengalami rasa nyeri atau dismenore daripada responden yang memiliki asupan zat besi normal. Hasil uji statistik menggunakan uji Rank Spearman menunjukkan bahwa nilai koefisien korelasi sebesar -0.586 dan $p$-value sebesar $0.000 \quad(p<0.05) \quad$ yang berarti ada hubungan yang signifikan antara asupan zat besi dengan kejadian dismenore pada siswi di SMK Batik 2 Surakarta. Koefisien korelasi sebesar 0.586 menunjukkan adanya hubungan yang sedang antara kedua variabel (Sugiyono, 2002). Nilai $r$ yang negatif menunjukkan bahwa semakin tinggi asupan zat besi maka rasa nyeri dismenore semakin berkurang.

Hasil penelitian ini sesuai dengan penelitian yang dilakukan oleh Dewi (2014) yang menunjukkan adanya hubungan anemia dengan kejadian dismenore pada remaja putri kelas XI di SMA N 2 Ungaran. Hasil uji statistik dengan menggunakan uji Chi-Square didapatkan nilai $p$-value 0.023 ( $\mathrm{p}<0.05)$.

Zat besi sangat diperlukan untuk pembentukan hemoglobin $(\mathrm{Hb})$ di dalam sumsum tulang. Kekurangan zat besi menyebabkan penurunan kadar zat besi plasma, sehingga suplai zat besi ke dalam sumsum tulang menjadi berkurang, sehingga hal ini menurunkan pembentukan hemoglobin dan mengakibatkan anemia. Anemia merupakan salah satu faktor yang dapat menyebabkan berkurangnya daya tahan tubuh terhadap rasa nyeri ketika menstruasi. Hal inilah yang dapat menyebabkan terjadinya dismenore.

\section{Keterbatasan Penelitian}

Penilitian ini memiliki beberapa keterbatasan yaitu:

a. Adanya faktor-faktor lain yang dapat menyebabkan terjadinya dismenore tetapi tidak diteliti, seperti: faktor kejiwaan, sumbatan di saluran leher rahim, organ reproduksi wanita, endokrin, alergi, menarche, dan aktivitas fisik.

b. Penggunaan form food frequency semi kuantitatif yang hanya menyantumkan 
makanan sumber kalsium dan sumber zat besi, mengakibatkan makanan lain yang memiliki kandungan kalsium dan zat besi lebih sedikit menjadi tidak terhitung walaupun makanan tersebut dikonsumsi setiap hari atau sering.

\section{KESIMPULAN}

1. Siswi SMK Batik 2 Surakarta yang memiliki asupan kalsium kategori kurang sebesar $83.6 \%$ dan asupan kalsium kategori normal sebesar $16.4 \%$.

2. Siswi SMK Batik 2 Surakarta yang memiliki asupan zat besi kategori kurang sebesar $71.6 \%$ dan asupan zat besi kategori normal sebesar $28.4 \%$.

3. Kejadian dismenore pada siswi SMK Batik 2 Surakarta yang tidak nyeri sebesar $17.9 \%$, nyeri ringan sebesar $20.9 \%$, nyeri sedang 1 sebesar $22.4 \%$, nyeri sedang 2 sebesar $17.4 \%$, nyeri berat sebesar $16.4 \%$, dan nyeri tak tertahankan sebesar $4.5 \%$.

4. Terdapat hubungan antara asupan kalsium dengan kejadian dismenore pada siswi SMK Batik 2 Surakarta. Sebagian besar siswi memiliki asupan kalsium yang rendah dan mengalami dismenore.

5. Terdapat hubungan antara asupan zat besi dengan kejadian dismenore pada siswi SMK Batik 2 Surakarta. Sebagian besar siswi memiliki asupan zat besi yang rendah dan mengalami dismenore.

\section{DAFTAR PUSTAKA}

Angka Kecukupan Gizi (AKG)., 2013, Jakarta.

Departemen Gizi dan Kesehatan Masyarakat Fakultas Kesehatan Masyarakat Universitas Indonesia., 2013, Gizi dan Kesehatan Masyatrakat edisi revisi, Rajawali Pers, Jakarta.

Dewi, FI., 2014, Hubungan Anemia dengan Kejadian Dismenorea pada Remaja Putri Kelas XI di SMA N 2 Ungaran, Skripsi, Program Studi DIV Kebidanan, Sekolah Tinggi Ilmu Kesehatan Ngudi Waluyo, Ungaran.

Dieny, FF., 2014, Permasalahan Gizi pada Remaja Putri, Graha Ilmu, Yogyakarta.

Jacobs-Thys S., 2000, Micronutrients and The Premenstrual Syndrome: The Case for Calcium. Journal American College of Nutrition, 2 (19):220-227

Oktabriawatie, D., Mulyani, EY., Herlianti, MP., 2009, Konsumsi Kalsium dan Keluhan Menstruasi pada Remaja Putri di SMA Negeri 6 Tangerang. Vol 2, No 2

Proverawati, A., dan Misaroh, S., 2009, Menarche, Nuha Medika, Yogyakarta.

Puspasari, P., 2004, Gambaran Asupan Kalsium dan Beberapa Faktor yang Berhubungan pada Remaja SMAN Kota Bandung Tahun 2004, Skripsi, Fakultas Kesehatan Masyarakat Universitas Indonesia, Depok. 
Sinaga, FBR., 2012, Hubungan Asupan Kalsium Dengan Tingkat Dismenore Pada Remaja Putri Vegan Di Vihara Maitreya Medan Tahun 2011. Skripsi: Universitas Sumatera Utara Medan. Fakultas Kesehatan Masyarakat.

Sophia, F., Muda, S., Jemadi., 2013, Faktor-Faktor yang Berhubungan dengan Dismenore pada Siswi SMK Negeri 10 Medan Tahun 2013, Fakultas Kesehatan Masyarakat Universitas Sumatra Utara.

Sugiyono., 2002, Metodologi Penelitian Administrasi, Alfabeta Widjanarko Dismenore Tinjauan Terapi pada Dismenore Primer, Majalah Kedokteran Damianus, Bandung Volume 5. No1, Januari 2006.

Supariasa, I., 2002, Penilaian Status Gizi, EGC, Jakarta.

Sylvia, W and M. Lorrainne., 2006, Patofisologi, Penerbit Buku Kedokteran EGC, Jakarta.

Widjanarko, B., 2006, Dismenore Tinjauan Terapi pada Dismenore Primer. Majalah Kedokteran Damianus, Volume 5. No1, Januari 2006.

Yahya, N., 2011, Kesehatan Reproduksi Pranikah, PT. Tiga Serangkai Pustaka Mandiri, Surakarta.

Yuliarti, N., 2009, The Vegetarian Way. Penerbit Andi, Yogyakarta. 